\title{
Potensi Pengembangan Budidaya Rumput Laut Eucheuma Cottonii Di Kawasan Perairan Kelurahan Serangan Kota Denpasar Berbasis Sistem Informasi Geografis
}

\author{
I Wayan Sri Adi Wiryana, Dewa Gede Semara Edi, I Made Kawana \\ Program Studi Manajemen Sumber Daya Perairan, Fakultas Pertanian, Universitas Warmadewa \\ Email : i.w.s.adiwiryana@gmail.com
}

\begin{abstract}
Distric of Serangan in Denpasar City Bali Province is an area that has economic, social and ecological value that is very meaningful for the survival of the surrounding community. Considering the potential of seaweed cultivation of Eucheuma cottonii that is not yet optimal in Serangan Village area, it needs to be optimized to measure the potential of seaweed cultivation, to map and determine the location of the potential of seaweed cultivation, to make recommendation of potential sea cultivation location. This research aims (1) To know the potential of seaweed cultivation in Serangan urban area, Denpasar City; (2) To be able to know the area for the development of seaweed cultivation which is potential in Serangan Urban Village Denpasar area. The process of determining the suitability of the area is done by using spatial operation by utilizing GIS application. The method of determining the research point for field observation is done by purposive random sampling, where the determination of research point is done deliberately based on certain considerations. Considerations taken include the current location of cultivation areas, the ideal seaweed cultivation criteria, transportation, safety of researchers, time and cost. All the data collected from the field is analyzed digitally using software QGIS 2.14.0 and Cygwin64 Terminal with interpolasi technique. The result of this research shows that the potential of seaweed cultivation of Eucheuma cottonii in Eucheuma cottonii seaside area is 873,400 sqm. The potential area for the development of seaweed cultivation of Eucheuma cottonii in Serangan Village area of 873,400 sqm if the utilization is 30\% of the proper location, then the area that can be used is $262.020 \mathrm{m2}$, now has been utilized for the cultivation of seaweed Eucheuma cottonii covering $27,488 \mathrm{~m} 2$ so that the remaining potential areas to be developed as the location of seaweed cultivation Eucheuma cottonii covering an area of $234,531 \mathrm{~m}^{2}$.
\end{abstract}

Keywords: Eucheuma cottonii, distric of serangan, geographic information system

\section{Pendahuluan}

Indonesia merupakan negara maritim dengan potensi perikanan yang sangat besar. Sekitar dua per tiga dari luas wilayah Indonesia merupakan laut, dengan cakupan area mencapai sekitar 5.8 juta, yang dibatasi oleh garis pantai sepanjang $95.18 \mathrm{~km}$ dan mengelilingi lebih dari 18.000 pulau. Keadaan geografis yang baik disertai dengan Indonesia yang beriklim tropis menghasilkan keanekaragaman dan produktivitas biota laut yang tinggi (Tarigan, 2015).

Salah satu sumber daya hayati laut Indonesia yang potensial adalah rumput laut. Perairan yang kaya akan mineral dan sinar matahari yang dimiliki Indonesia merupakan lahan subur untuk pertumbuhan rumput laut. Sebagai negara kepulauan yang memiliki potensi pengembangan rumput laut ini seyogyanya Indonesia menjadi produsen utama komoditas rumput laut di pasar dunia. Areal strategis yang dapat digunakan untuk budidaya rumput laut di seluruh Indonesia meliputi wilayah seluas \pm 1.380.931 ha. Potensi daerah sebaran rumput laut di Indonesia sangat luas, baik yang tumbuh secara alami maupun yang dibudidayakan. Tersebar hampir di seluruh wilayah seperti Sumatera, Jawa, Bali, Nusa Tenggara, Kalimantan, Sulawesi, Maluku, dan Papua (Anggadiredja, 2008 dalam Hidayati, 2009 ).

Pulau Bali merupakan salah satu pulau penghasil rumput laut di Indonesia. Bali memiliki potensi pengembangan rumput laut seluas 800 ha dan baru dimanfaatkan 481 ha atau 55\%. Potensi tersebut tersebar di perairan lima kabupaten yang meliputi Kabupaten Klungkung, Karangasem, Badung, Buleleng dan Kota Denpasar (Dinas Kelautan dan Perikanan Provinsi Bali, 2009). 
Salah satu jenis rumput laut yang dibudidayakan oleh masyarakat Bali adalah Eucheuma cottonii. Jenis ini banyak dibudidayakan karena teknologi produksinya relatif murah dan mudah serta penanganan pasca panen relatif sederhana. Selain sebagai bahan baku industri, rumput laut jenis Eucheuma cottonii juga dapat diolah menjadi makanan yang dapat dikonsumsi secara langsung (Wijayanto dkk, 2003). Pengembangan budidaya rumput laut Eucheuma cottonii sudah cukup instensif, namun mengalami penurunan dan ketidak stabilan sebelumnya. Penurunan suatu produksi rumput laut Eucheuma cottonii dapat disebabkan antara lain oleh lemahnya teknologi budidaya baik bibit, metode budidaya, umur panen, dan penanganan pasca panen, serta pemilihan lokasi budidaya yang kurang sesuai, hal yang sama terjadi di Kelurahan Serangan, Kota Denpasar Provinsi Bali yang juga mengalami penurunan dan ketidak stabilan produksi rumput laut Eucheuma cottonii sebelumnya.

Kawasan Kelurahan Serangan di Kota Denpasar, Provinsi Bali merupakan kawasan yang mempunyai nilai ekonomi, sosial dan ekologis yang sangat berarti bagi kelangsungan hidup masyarakat di sekitarnya. Perikanan di wilayah Kelurahan Serangan merupakan salah satu bidang yang diharapkan dapat dan mampu menjadi penopang perekonomian rakyat di kawasan sekitar Kota Denpasar. Untuk saat ini, potensi budidaya rumput laut Eucheuma cottonii belum optimal di kawasan Kelurahan Serangan, maka perlu dioptimalkan sebagai daerah pengembangan budidaya rumput laut Eucheuma cottonii diwilayah Kota Denpasar, walaupun di beberapa bagian pulau karakteristiknya bervariasi. Oleh karena pentingnya informasi tentang di lokasi perairan laut di Kelurahan Serangan yang dapat dimanfaatkan untuk budidaya rumput laut Eucheuma cottonii, masih sangat terbatas maka suatu studi pemetaan dan potensi pengembangan budidaya rumput laut Eucheuma cottonii di kawasan Kelurahan Serangan sangat mendesak untuk dilakukan guna bertujuan mengukur potensi budidaya rumput laut Eucheuma cottonii, memetakan dan menentukan lokasi potensi budidaya rumput laut Eucheuma cottonii, serta menyusun rekomendasi kawasan budidaya laut rumput laut Eucheuma cottonii yang potensial.

\section{Bahan dan Metode}

\subsection{Waktu dan Lokasi Penelitian}

Penelitian ini dilaksanakan di Kelurahan Serangan Kecamatan Denpasar Selatan Kota Denpasar, Provinsi Bali. Penelitian ini dilaksanakan pada tanggal 1 Juni 2016 sampai dengan 30 Juli 2016. Tahap dari penelitian yang dilakukan di Kelurahan Serangan Kecamatan Denpasar Selatan Kota Denpasar Provinsi Bali, meliputi persiapan hingga pengambilan data (Gambar 1).

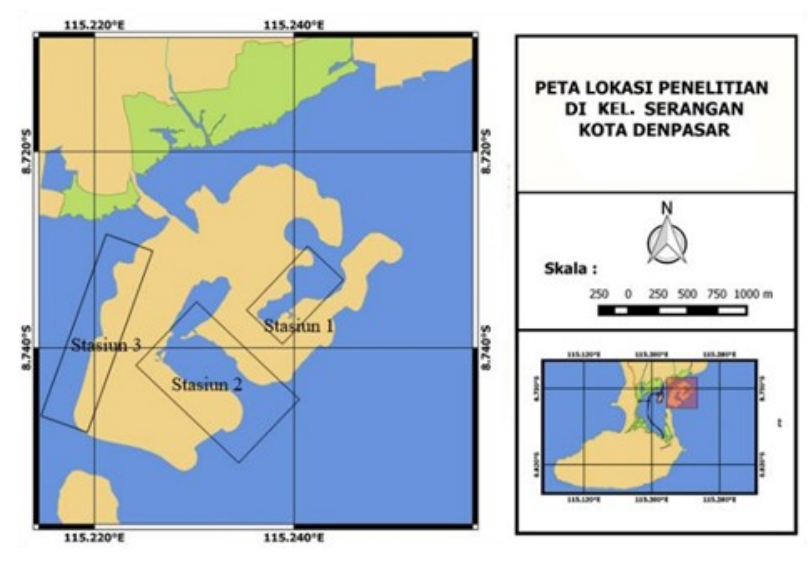

Gambar 1 


\subsection{Rancangan Penelitian}

\section{Peta Lokasi Penelitian}

Proses penentuan kesesuaian kawasan tersebut dilakukan dengan menggunakan operasi spasial dengan memanfaatkan aplikasi sistem informasi geografis. Metode penentuan titik penelitian untuk observasi lapangan dilakukan secara purposive random sampling, dimana penentuan titik penelitian dilakukan secara sengaja berdasarkan pertimbangan-pertimbangan tertentu. Pertimbangan yang diambil antara lain berupa daerah lokasi budidaya yang ada saat ini, kriteria kawasan budidaya rumput laut yang ideal, transportasi, keselamatan peneliti, waktu dan biaya.

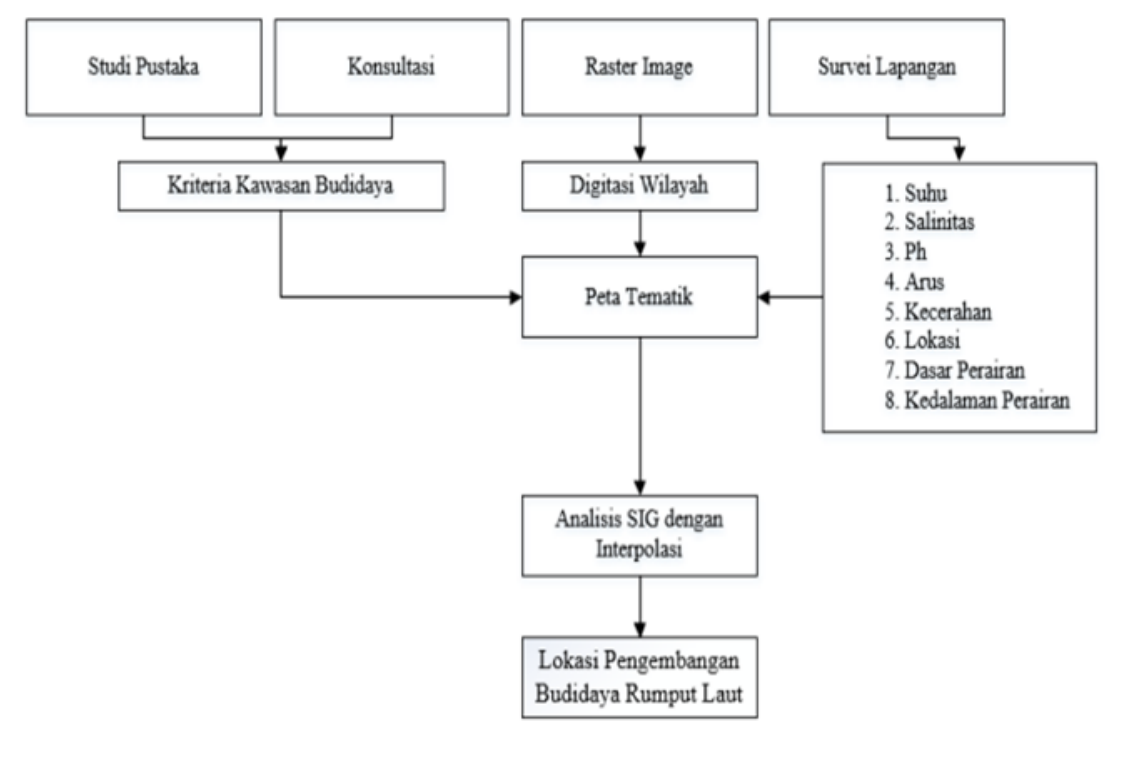

Gambar 2

Diagram Alir Rancangan Penelitian

Dalam penentuan titik penelitian di lapangan dan penetuan posisi menggunakan alat GPS (Global Positioning System). Data yang dikumpulkan terdiri dari data primer dan data sekunder. Data primer terdiri dari data spasial dan hasil pengukuran dilapangan, sementara data sekunder diperoleh dari studi pustaka dan dari instansi terkait.

\subsection{Alat dan Bahan}

Alat dan bahan yang digunakan dalam penelitian ini dapat dilihat pada Tabel 1 dan 2 di bawah ini:

Tabel 1

Daftar Alat Penelitian

\begin{tabular}{ccc}
\hline No & Jenis Alat & Kegunaan \\
\hline 1 & Thermometer & Mengukur Suhu \\
2 & Meteran & Mengukur Kedalaman \\
3 & Floating roach \& Stopwatch & Mengukur Kecepatan Arus \\
4 & Secchi Disc & Mengukur Kecerahan Kecerahan \\
5 & Refraktometer & Mengukur Salinitas \\
6 & pH Meter & Mengukur pH \\
7 & Global Positioning System (GPS) & Menentukan Posisi \\
8 & Data Sheet dan Alat Tulis & Mencatat data yang didapat dari penelitian \\
9 & Kamera Digital & Dokumentasi Kegiatan Penelitian \\
\hline
\end{tabular}


Potensi Pengembangan Budidaya Rumput Laut Eucheuma Cottonii Di Kawasan Perairan Kelurahan Serangan Kota Denpasar Berbasis Sistem Informasi Geografis

\begin{tabular}{ccc}
\hline \hline 10 & Alat Dasar Selam & Ground Check Lokasi \\
11 & QGIS 2.14.0 & Software GIS \\
12 & PC & Pengerjaan Analisis \\
\hline \multicolumn{3}{c}{ Tabel 2 } \\
\multicolumn{3}{c}{ Daftar Bahan Penelitian } \\
\hline No & Jenis Bahan & Kegunaan \\
\hline 1 & Raster Image Google Earth & Dasar Pembuatan Peta Tematik \\
2 & Aquades & Kalibrasi Alat \\
\hline
\end{tabular}

\subsection{Metode Penelitian}

\section{Penentuan Sumber Data}

Data dan informasi yang dibutuhkan dalam penelitian ini terbagi menjadi dua kategori yaitu data primer dan data sekunder.

\section{a. Data Primer}

Data Primer yang digunakan adalah data meliputi data hasil pengukuran lapangan seperti suhu, salinitas, $\mathrm{pH}$, arus, kecerahan, lokasi budidaya, dasar perairan, dan kedalaman perairan, yang kemudian diolah menjadi data sebaran spasial pada beberapa parameter dari pengukuran dilapangan.

\section{b. Data Sekunder}

Data Sekunder yang digunakan meliputi literatur-literatur penunjang dan data pendukung lainnya. Data sekunder yang dibutuhkan ditelusuri dari hasil penelitian terdahulu, Dinas Peternakan Perikanan dan Kelautan Kota Denpasar, dan data dari instansi lain yang terkait dengan penelitian ini. Pengumpulan data sekunder dilakukan untuk memberikan masukan data ke dalam sistem informasi geografis.

\section{Studi Pustaka}

Studi pustaka atau literatur dimaksudkan untuk mendapatkan teori-teori, konsep-konsep, sebagai bahan pertimbangan terhadap hasil penelitian. Literatur yang dikaji dalam studi pustaka berkaitan langsung dengan permasalahan penelitian untuk memperoleh data yang bersifat teoritis dan konsep sebagai pendukung penelitian. Pada penelitian ini, studi pustaka dilakukan untuk mencari kriteria ideal kawasan yang optimal untuk pembudidayaan rumput laut jenis Eucheuma cottonii.

\section{Pengumpulan Data}

\section{a. Persiapan}

Sebelum penelitian ini dilakukan survei terlebih dahulu, yaitu survei lokasi penelitian langsung kelapangan. Survei penelitian terlebih dahulu dilakukan dimaksudkan untuk menentukan stasiun pengamatan sesuai dengan keseragaman karakteristik biofisik perairan yaitu keterlindungan dari gelombang, kecepatan arus, kedalaman, kecerahan dan habitat yang berbeda (berkarang, pasir dan lumpur) kemudian menandai wilayah yang ditentukan dengan menggunakan GPS.

\section{b. Pengumpulan Data Primer}

Tahapan pengumpulan data primer pada penelitian ini terbagi menjadi dua yaitu tahap pengumpulan basis data dan pengolahan citra dari google earth. Pengumpulan basis data dilakukan dengan mengumpulkan data lapangan dari setiap parameter yang terdiri atas suhu, salinitas, $\mathrm{pH}$, kecepatan arus, 
Potensi Pengembangan Budidaya Rumput Laut Eucheuma Cottonii Di Kawasan Perairan Kelurahan Serangan Kota Denpasar Berbasis Sistem Informasi Geografis

kecerahan, lokasi budidaya, tipe substrat dasar perairan, dan kedalaman perairan. Pengumpulan data lapangan dilakukan pada kondisi surut terendah untuk mengetahui kawasan yang masih tergenang oleh air laut saat surut terendah, sesuai dengan Standar Nasional Indonesia 7579.1: (2010) bahwa kedalaman perairan yang baik untuk budidaya rumput laut Eucheuma cottoni dengan menggunakan metode lepas dasar adalah 0,1 meter pada waktu surut terendah dan 4 meter pada saat kondisi pasang tertinggi, hal ini disebabkan rumput laut akan terhambat pertumbuhannya apabila langsung terpapar oleh sinar matahari secara langsung saat surut terendah.

\section{Pengukuran Suhu}

Untuk mengukur Suhu alat yang digunakan adalah thermometer. Pengukuran suhu dilakukan dengan mencelupkan thermometer kedalam air laut kemudian diamati suhu yang tertera pada thermometer. Setelah itu hasil pengamatan dicatat kedalam data sheet.

\section{Pengukuran Salinitas}

Salinitas diukur dengan alat refraktometer. Pengukuran salinitas dilakukan dengan cara air sampel diteteskan di bagian sensor refraktometer dan diarahkan kesinar matahari kemudian lihat angka yang ada pada refraktometer, angka yang merupakan kadar salinitas yaitu angka yang ditunjukkan dengan batasan warna biru dan putih. Setelah itu hasil pengamatan dicatat kedalam data sheet.

\section{Pengukuran $\mathrm{pH}$}

Untuk mengukur $\mathrm{pH}$ alat yang digunakan adalah $\mathrm{pH}$ meter. Pengukuran salinitas dilakukan dengan cara sensor pada alat pH Meter dicelupkan kedalam air sampel kemudian ditunggu beberapa saat hingga angka yang menunjukan $\mathrm{pH}$ pada layar stabil/konstan (tidak berubah). Setelah itu hasil pengamatan dicatat kedalam data sheet.

\section{Pengukuran Kecerahan}

Untuk mengukur kecerahan alat yang digunakan adalah sechi disk. Pengukuran tingkat kecerahan perairan dilakukan dengan cara sechi disk diturunkan sampai kedalaman tertentu kemudian diukur kecerahannya sampai dengan batas penglihatan, setelah itu hasil pengamatan dicatat kedalam data sheet.

\section{Lokasi Budidaya dan Dasar Perairan}

Pengamatan lokasi dan dasar perairan dilakukakan dengan mengecek keterlindungan lokasi dari ombak dan kondisi substrat dasar perairan (berkarang, berpasir atau berlumpur). Setelah itu hasil pengamatan dicatat kedalam data sheet.

\section{Pengukuran Kedalaman Perairan}

Untuk mengukur kedalaman perairan digunakan alat meteran. Pengukuran Kedalaman Perairan dilakukan dengan cara meteran diturunkan sampai menyentuh dasar perairan kemudian panjangnya meteran dilihat untuk menentukan kedalam perairannya. Setelah itu hasil pengamatan dicatat kedalam data sheet.

\section{Pengukuran Kecepatan Arus}

Untuk mengukur kecepatan arus alat yang digunakan adalah floating roach dan stopwatch. Cara pengukurannya dengan menurunkan alat tersebut ke permukaan air. Untuk mendapatkan nilai kecepatan arus maka dihitung sampai sejauh mana alat tersebut dibawa oleh arus. Standar yang digunakan adalah tali yang diikatkan pada floating roach. Apabila floating roach tersebut berpindah atau dibawa oleh arus, maka tali itu akan renggang, sehingga dengan demikian dapat ketahui bahwa floating roach tersebut 
sudah berpindah sepanjang tali yang telah ditentukan. Misalnya panjang tali 5 meter, memerlukan berapa waktu yang telah ditentukan sampai berpindah dari tempat semula. Dari uraian tersebut dapat diperjelas dengan rumus $\mathrm{v}=\mathrm{s} / \mathrm{t}$ dimana $\mathrm{v}=$ kecepatan $\operatorname{arus}(\mathrm{m} / \mathrm{dtk}), \mathrm{s}=$ jarak tempuh $(\mathrm{m})$, dan $\mathrm{t}=$ waktu (detik). Setelah itu hasil pengamatan dicatat kedalam data sheet.

Sedangkan tahap pengolahan citra dari google earth bertujuan untuk mendapatkan data yang tidak diperoleh dari instansi maupun hasil pengumpulan data lapangan sehingga dapat melengkapi dari parameter penentu kesesuaian lokasi budidaya rumput laut Eucheuma cottonii. Tahap awal yang dilakukan dalam pengolahan raster image yaitu digitasi raster yang bertujuan untuk merubah raster kedalam bentuk vektor.

c. Pengumpulan Data Sekunder

Data sekunder antara lain diperoleh dari hasil-hasil penelitian, literatur-literatur penunjang dan petapeta yang berhubungan dengan lokasi penelitian.

\subsection{Analisa Data}

\section{Analisis dengan Sistem Informasi Geografis}

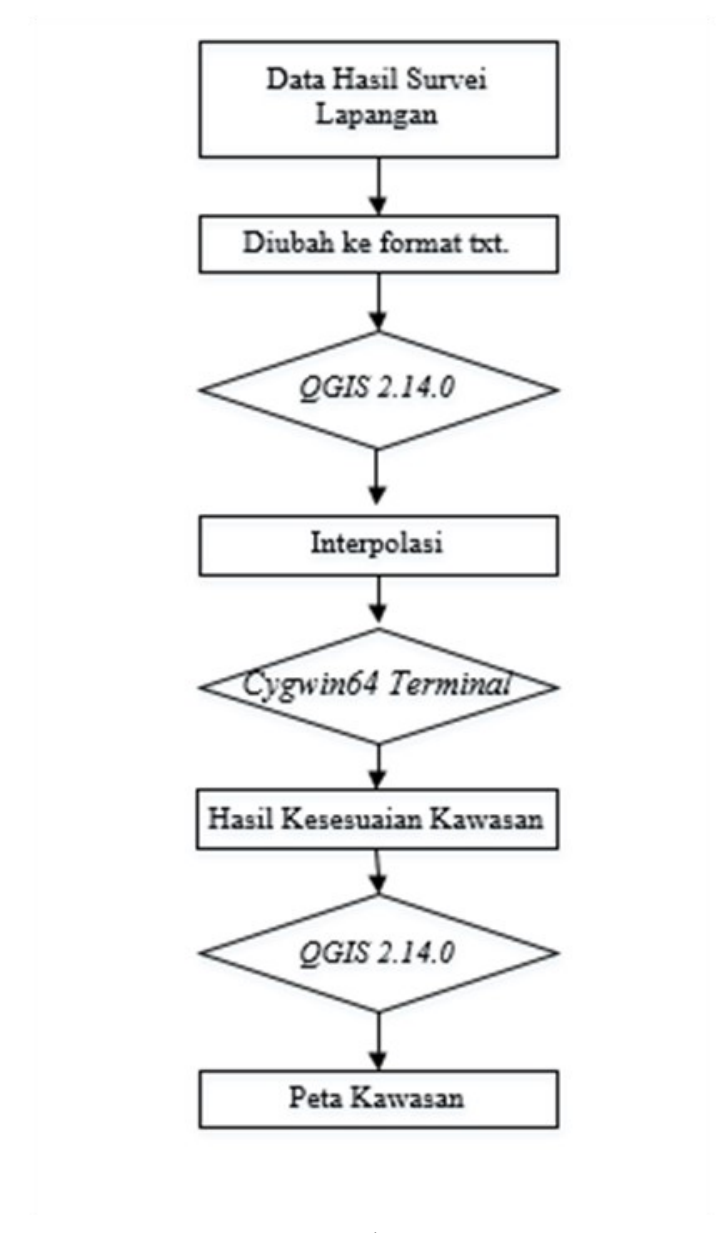

Gambar 3

Diagram alir proses analisis Sistem Informasi Geografis

Seluruh data yang dikumpulkan dari lapangan dianalisa secara digital menggunakan software $Q G I S$ 
Potensi Pengembangan Budidaya Rumput Laut Eucheuma Cottonii Di Kawasan Perairan Kelurahan Serangan Kota Denpasar Berbasis Sistem Informasi Geografis

2.14.0 dan Cygwin64 Terminal dengan teknik interpolasi. Teknik interpolasi merupakan proses memprediksi nilai pada suatu titik yang bukan merupakan titik sampel, berdasarkan pada nilai-nilai dari titik-titik di sekitarnya yang berkedudukan sebagai sampel (Burrough dan McDonell, 1998 dalam Hadi, 2013). Hasil interpolasi kemudian akan memberi informasi mengenai kawasan dengan kriteria yang sesuai untuk budidaya rumput laut Eucheuma cottonii.

\section{Pembuatan Peta Kawasan}

Pembuatan Peta kawasan dibuat berdasarkan kesesuaian lokasi budidaya rumput laut Eucheuma cottonii. Basis data dibentuk dari data spasial dan data atribut, kemudian dibuat dalam bentuk layers atau coverage dimana menghasilkan peta-peta tematik dalam format digital sesuai kebutuhan/parameter masing-masing jenis kesesuaian lokasi. Setelah basis data terbentuk, analisis spasial dilakukan dengan metode tumpang susun (overlay) terhadap keseluruhan parameter yang datanya telah disatukan dalam satu kertas kerja ke bentuk polygon. Data tersebut kemudian di tumpang susunkan (overlay) dengan polygon kawasan budidaya rumput laut Eucheuma cottonii yang dimanfaatkan masyarakat di kawasan Kelurahan Serangan saat ini, sehingga informasi spasialnya dapat diketahui :

1. Potensi budidaya rumput laut Eucheuma cottonii di kawasan Kelurahan Serangan.

2. Luas kawasan untuk pengembangan budidaya rumput laut Eucheuma cottonii yang potensial di kawasan Kelurahan Serangan.

\section{Hasil dan Pembahasan}

\subsection{Hasil Pengamatan}

\section{Sebaran Suhu}

Sebaran suhu di Kawasan Perairan Kelurahan Serangan Kota Denpasar terdapat empat kelas berdasarkan hasil penelitian yang diukur pada kondisi surut terendah yaitu kawasan yang tidak tergenang air laut, 27,7oC -28,2 oC, 28,3 oC -28,6 oC, dan 28,7 oC -29,0 oC.

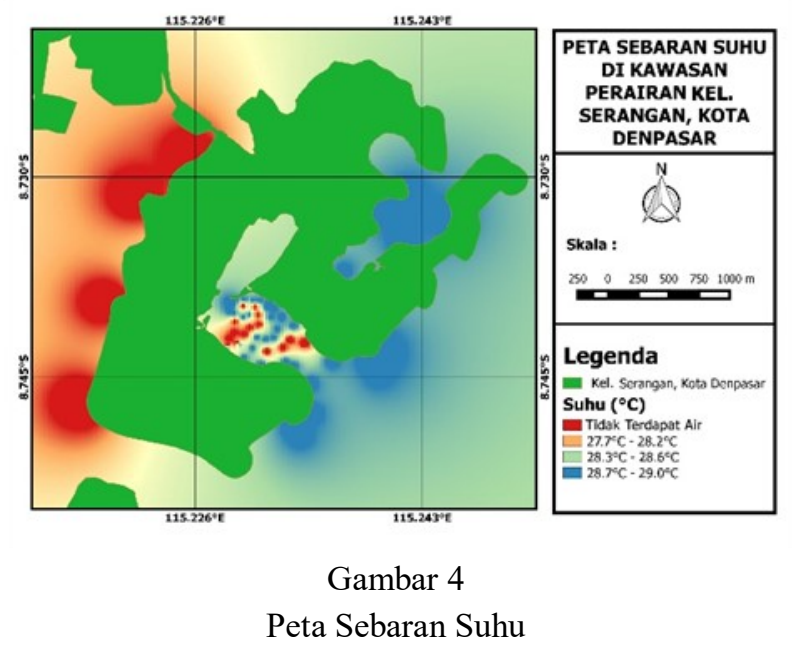

\section{Sebaran Salinitas}

Sebaran salinitas di Kawasan Perairan Kelurahan Serangan Kota Denpasar terdapat lima kelas berdasarkan hasil penelitian yang diukur pada kondisi surut terendah yaitu kawasan yang tidak tergenang 
Potensi Pengembangan Budidaya Rumput Laut Eucheuma Cottonii Di Kawasan Perairan Kelurahan Serangan Kota Denpasar Berbasis Sistem Informasi Geografis

air laut, 30,0 \%o-31,6 \%o, 31,7 \%o-32,2 \%o, 32,3 \%o-32,6 \%o, dan 32,7 \%o-33,0 \%o.

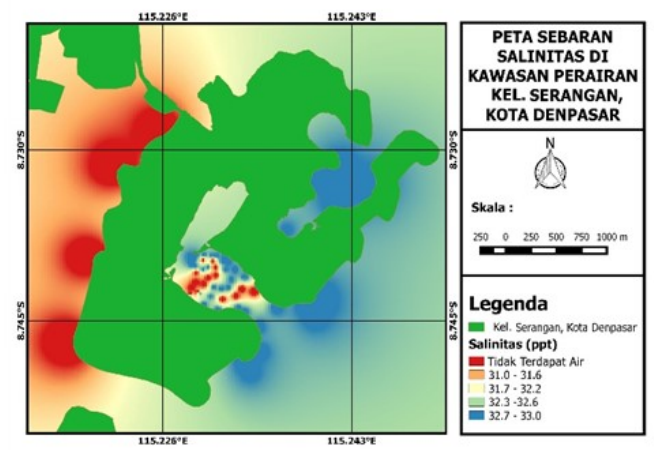

Gambar 5

\section{Sebaran pH}

Peta Sebaran Salinitas

Sebaran pH di Kawasan Perairan Kelurahan Serangan Kota Denpasar terdapat empat kelas berdasarkan hasil penelitian yang diukur pada kondisi surut terendah yaitu kawasan yang tidak tergenang air laut, 7,0, 8,0, dan 8,1.

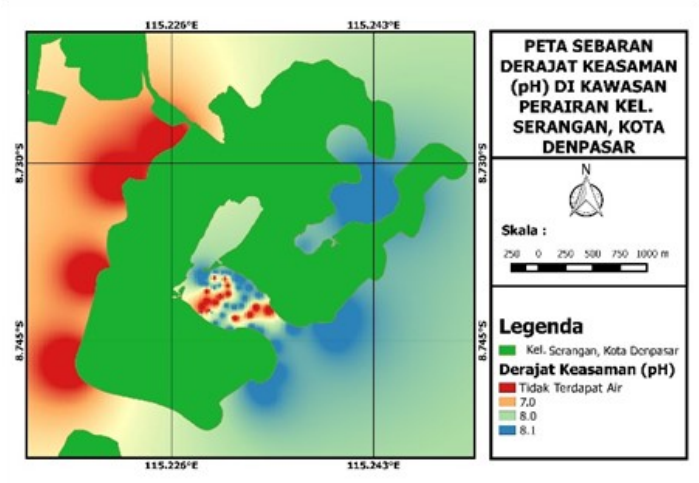

Gambar 6

\section{Sebaran Kecepatan Arus}

Peta Sebaran $\mathrm{pH}$

Sebaran kecepatan arus di Kawasan Perairan Kelurahan Serangan Kota Denpasar terdapat empat kelas berdasarkan hasil penelitian yang diukur pada kondisi surut terendah yaitu kawasan yang tidak tergenang air laut, $0,1 \mathrm{~m} / \mathrm{s}, 0,2 \mathrm{~m} / \mathrm{s}, 0,3 \mathrm{~m} / \mathrm{s}, 0,4 \mathrm{~m} / \mathrm{s}$.

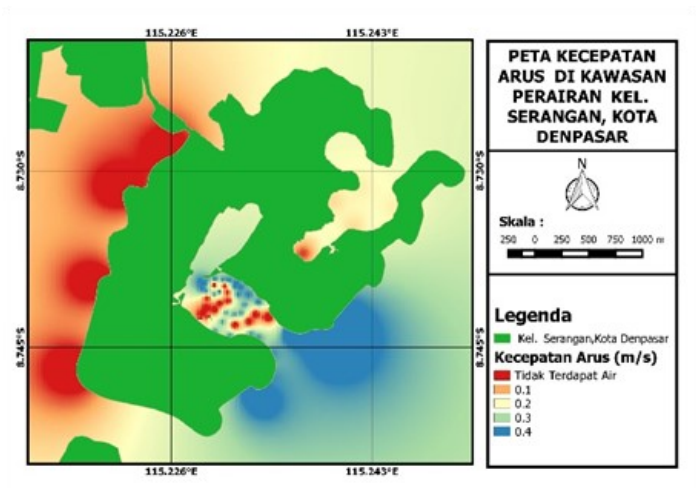




\section{Sebaran Kecerahan Perairan}

Gambar 7

Peta Sebaran Kecepatan Arus

Sebaran Kecerahan Perairan di Kawasan Perairan Kelurahan Serangan Kota Denpasar terdapat lima kelas berdasarkan hasil penelitian yang diukur pada kondisi surut terendah yaitu kawasan yang tidak tergenang air laut, $0,2 \mathrm{~m}-0,3 \mathrm{~m}, 0,4 \mathrm{~m}-0,5 \mathrm{~m}, 0,6 \mathrm{~m}-0,7 \mathrm{~m}, 1,2 \mathrm{~m}-1,3 \mathrm{~m}$.

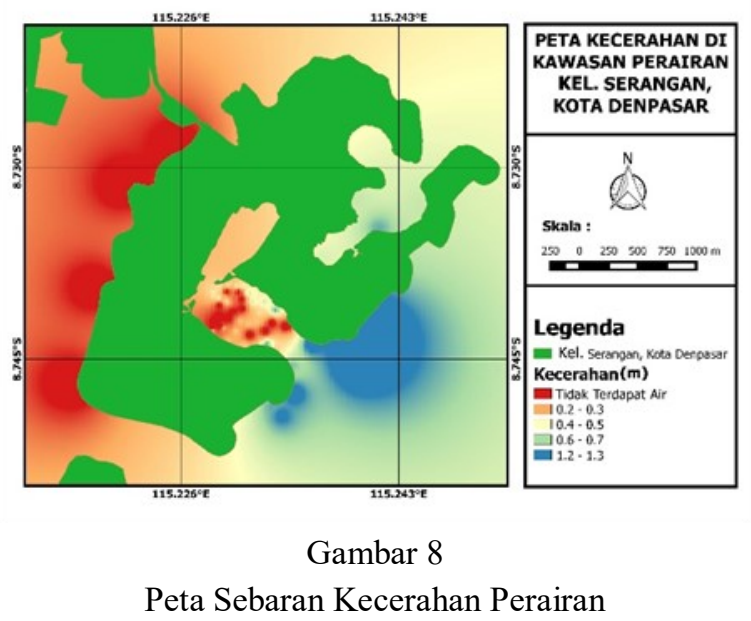

\section{Sebaran Kedalaman Perairan}

Sebaran Kedalaman Perairan di Kawasan Perairan Kelurahan Serangan Kota Denpasar terdapat lima kelas berdasarkan hasil penelitian yang diukur pada kondisi surut terendah yaitu kawasan yang tidak tergenang air laut, $0,2 \mathrm{~m}-0,3 \mathrm{~m}, 0,4 \mathrm{~m}-0,5 \mathrm{~m}, 0,6 \mathrm{~m}-0,7 \mathrm{~m}, 1,2 \mathrm{~m}-1,3 \mathrm{~m}$.

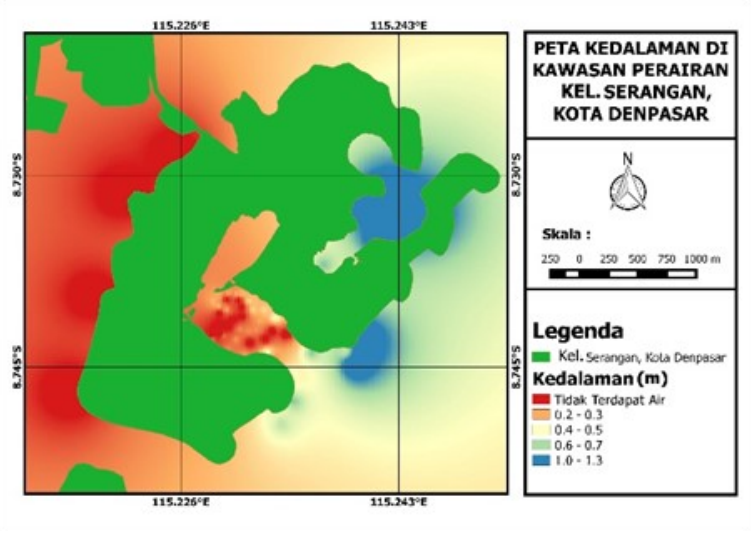

Gambar 9

\section{Lokasi dan Dasar Perairan}

Peta Sebaran Kedalaman Perairan

Lokasi yang dipilih untuk titik pengamatan telah memperhitungkan keterlindungan dari hempasan gelombang yang keras, sementara sebaran kondisi Dasar Perairan di Kawasan Perairan Kelurahan Serangan Kota Denpasar terdapat 3 jenis substrat berdasarkan hasil penelitian yang diukur pada kondisi surut terendah yaitu yaitu Pasir Halus, Pasir Belumpur dan Pasir Berkarang. 


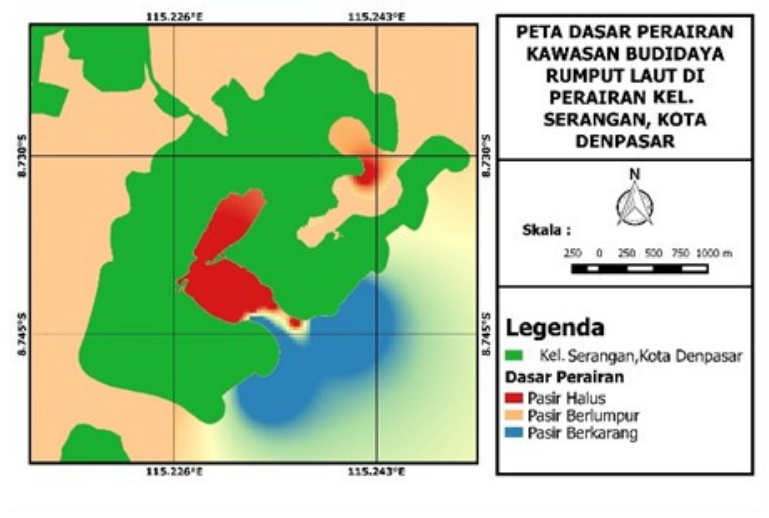

Gambar 10

Peta Sebaran Kondisi Dasar Perairan

\section{Hasil Pengamatan Kawasan Budidaya Rumput Laut di Kelurahan Serangan}

Kawasan Perairan Kelurahan Serangan Kota Denpasar berdasar kelayakan terdapat dua kelas berdasarkan hasil penelitian yang diukur pada kondisi surut terendah yaitu layak untuk budidaya rumput laut Eucheuma cottonii dan tidak layak untuk budidaya rumput laut Eucheuma cottonii.

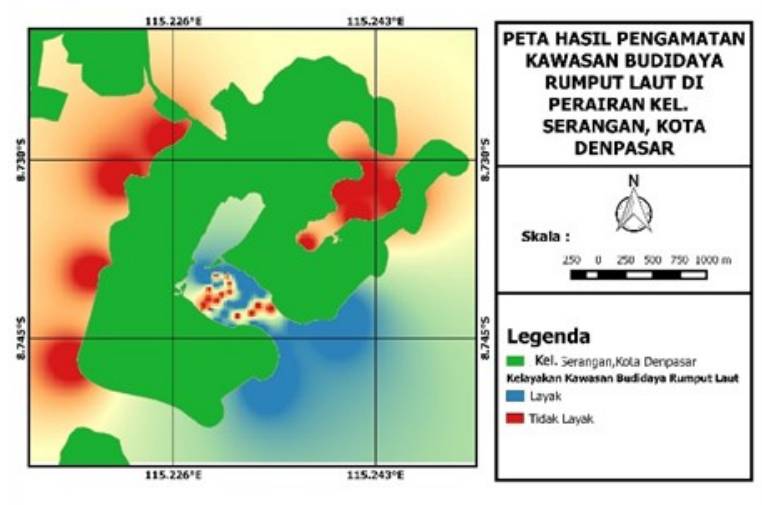

Gambar 11

Peta Hasil Pengamatan Kawasan Budidaya Rumput Laut di Kawasan Perairan Kelurahan Serangan Kota Denpasar

Adapun tingkat kesesuaian lokasi untuk budidaya rumput laut dapat dirinci (Table 3) sebagai berikut :

a. Layak

Pada daerah yang termasuk dalam kategori ini dicirikan dengan tidak adanya yang menghambat kegiatan budidaya Eucheuma cottonii. Seluruh kriteria yang mendukung membuat daerah ini sangat sesuai untuk mengembangkan budidaya rumput laut Eucheuma cottonii. Hasil analisis spasial yang dilakukan terhadap parameter tersebut, diketahui bahwa ternyata lokasi yang sangat sesuai berada pada stasiun 2 (dua).

b. Tidak Layak

Daerah-daerah yang termasuk dalam kategori ini dicirikan dengan adanya penghambat kegiatan budidaya Eucheuma cottonii. Hasil analisis spasial yang dilakukan terhadap parameter tersebut, diketahui bahwa ternyata lokasi yang tidak sesuai berada pada stasiun 1 (satu) dan 3 (tiga). 
Potensi Pengembangan Budidaya Rumput Laut Eucheuma Cottonii Di Kawasan Perairan Kelurahan Serangan Kota Denpasar Berbasis Sistem Informasi Geografis

Tabel 3

Kelayakan Masing-Masing Stasiun

\begin{tabular}{|c|c|c|c|c|c|c|c|c|}
\hline Stasiun & Suhu & $\begin{array}{l}\text { Salinitas } \\
\text { (ppt) }\end{array}$ & pH & $\begin{array}{c}\text { Kecepata } \\
\text { n Arus } \\
(\mathbf{m} / \mathbf{s})\end{array}$ & Kecerahan & Lokasi & $\begin{array}{c}\text { Dasar } \\
\text { Perairan }\end{array}$ & $\begin{array}{c}\text { Kedalaman } \\
\text { Perairan }\end{array}$ \\
\hline 1 & Layak & Layak & Layak & $\begin{array}{l}\text { Tidak } \\
\text { Layak }\end{array}$ & Layak & Layak & $\begin{array}{l}\text { Tidak } \\
\text { Layak }\end{array}$ & Layak \\
\hline 2 & Layak & Layak & Layak & Layak & Layak & Layak & Layak & Layak \\
\hline 3 & $\begin{array}{l}\text { Tidak } \\
\text { Layak }\end{array}$ & $\begin{array}{l}\text { Tidak } \\
\text { Layak }\end{array}$ & $\begin{array}{l}\text { Tidak } \\
\text { Layak }\end{array}$ & $\begin{array}{l}\text { Tidak } \\
\text { Layak }\end{array}$ & Tidak Layak & $\begin{array}{l}\text { Tidak } \\
\text { Layak }\end{array}$ & $\begin{array}{l}\text { Tidak } \\
\text { Layak }\end{array}$ & Tidak Layak \\
\hline
\end{tabular}

\subsection{Pembahasan}

Rumput laut Eucheuma cottonii bersifat fitobentik yang tumbuh dengan cara menempel pada substrat seperti pecahan karang, karang mati, fragment karang, atau pasir, sehingga penentuan lokasi budidaya rumput laut sangat penting untuk dilakukan berdasarkan sifat hidupnya. Sebelum menentukan kesesuaian lokasi budidaya rumput laut Eucheuma cottonii, maka ada beberapa hal yang harus diperhatikan yaitu : keamanan, konflik, kemudahan dan faktor kualitas perairan. Dari faktor keamanan, keterlindungan, dan konflik, dan kemudahan, kawasan perairan Kelurahan Serangan, Kota Denpasar pengembangan kawasan budidaya rumput laut Eucheuma cottonii dirancang dengan menghindari adanya konflik penggunaan lahan dengan kegiatan pariwisata dan pelayaran disekitarnya, letak lahan budidaya rumput laut yang dekat dengan daratan dan sehingga akan mudah dalam mengontrol kegiatan budidaya tersebut. Berdasarkan analisis spasial dengan menggunakan Sistem Informasi Geografis (SIG) dengan cara interpolasi diperoleh hasil analisis kesesuaian lokasi untuk budidaya rumput laut Eucheuma cottonii. Parameter yang digunakan dalam menganalisis kesesuaian lokasi untuk budidaya rumput laut meliputi 8 (delapan) parameter yaitu suhu, salinitas, $\mathrm{pH}$, kecepatan arus, kecerahan, keterlindungan lokasi, jenis substrat dasar perairan dan kedalaman perairan diperoleh hasil diketahui kawasan yang memenuhi kriteria untuk budidaya rumput laut Eucheuma cottonii adalah seluas 87,34 ha, sementara luas kawasan yang baru dimanfaatkan saat ini seluas 2,74 ha seperti terlihat pada gambar 12 dibawah.

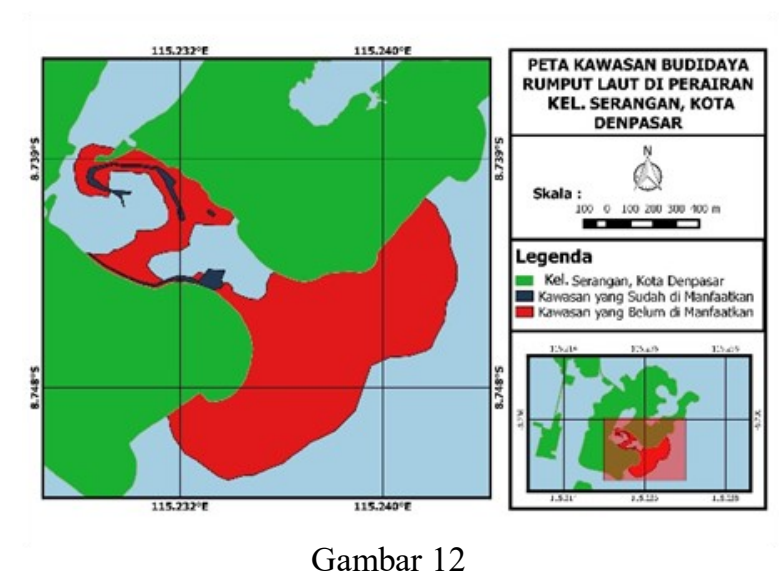

Peta Kawasan yang Layak untuk Budidaya Rumput Laut di Kawasan Perairan Kelurahan Serangan Kota Denpasar

Perairan Kelurahan Serangan merupakan perairan yang bersifat milik umum (common property), sehingga akan muncul persoalan dalam penanganan para pengguna lokasi tanpa pembatasan tentang siapa yang berhak dan tidak berhak memanfaatkan lokasi tersebut. Hal ini dapat menyebabkan berkembangnya budidaya rumput laut Eucheuma cottonii yang melebihi kapasitas daya dukung perairan tersebut sehingga berdampak negatif terhadap lingkungan perairan (kualitas perairan). Hasil penelitian 
saat ini menunjukkan bahwa kondisi ekologis perairan Kelurahan Serangan pada saat penelitian masih dalam batas toleransi untuk budidaya rumput laut Eucheuma cottonii. Dengan demikian untuk pengembangan budidaya rumput laut Eucheuma cottonii yang berkelanjutan di perairan Kelurahan Serangan maka pemanfaatannya tidak lebih dari 30\% dari luas lokasi yang layak. Sedangkan 70\% lagi dimanfaatkan untuk kepentingan yang lain. Untuk budidaya rumput laut Eucheuma cottonii kawasan yang layak adalah 87,34 ha apabila pemanfaatannya $30 \%$ dari lokasi yang layak, maka luas lahan yang dapat digunakan sebesar 26,20 ha, saat ini telah dimanfaatkan untuk kegiatan budidaya rumput laut Eucheuma cottonii seluas 2,74 ha sehingga tersisa kawasan yang berpotensi untuk dikembangkan sebagai lokasi budidaya rumput laut Eucheuma cottonii seluas 23,45 ha.

\section{Kesimpulan}

Dari hasil penelitian yang telah dilakukan dapat disimpulkan Potensi budidaya rumput laut Eucheuma cottonii di kawasan Kelurahan Serangan laut Eucheuma cottonii adalah seluas 87,34 ha. Kawasan yang potensial untuk pengembangan budidaya rumput laut Eucheuma cottonii di kawasan Kelurahan Serangan seluas 87,34 ha apabila pemanfaatannya $30 \%$ dari lokasi yang layak, maka luas lahan yang dapat digunakan sebesar 26,20 ha, saat ini telah dimanfaatkan untuk kegiatan budidaya rumput laut Eucheuma cottonii seluas 2,74 ha sehingga tersisa kawasan yang berpotensi untuk dikembangkan sebagai lokasi budidaya rumput laut Eucheuma cottonii seluas 23,45 ha.

\section{Referensi}

Dinas Kelautan dan Perikanan Provinsi Bali (2009). Produksi Rumput Laut di Bali turun 15,2\%. http:// www.kabarbisnis.com/read/282238.

Hadi, B.S. (2013). Metode Interpolasi Spasial Dalam Studi Geografi. Universitas Negeri Yogyakarta. Yogyakarta.

Hidayati, W. (2009). Analisis Struktur, Perilaku Dan Keragaan Pasar Rumput Laut Eucheuma Cottoni : Kasus Di Kecamatan Mangarabombang, Kabupaten Takalar, Provinsi Sulawesi Selatan. Institut Pertanian Bogor. Bogor.

Standar Nasional Indonesia 7579.1: (2010). Mengenai Produksi Rumput Laut Kotoni (Eucheuma cottonii)-Bagian 1 : Metode Lepas Dasar.

Tarigan, G.R.B. (2015). Analisis Perkembangan dan Faktor-Faktor Yang Memengaruhi Ekspor Rumput Laut Indonesia Periode 1999-2013. Institut Pertanian Bogor. Bogor.

Wijayanto, T., Hendri, M., \& Aryawati, R. (2003). Studi Pertumbuhan Rumput Laut Eucheuma cottonii Berbagai Metode Penanaman yang berbeda di Perairan Kalianda, Lampung Selatan Program Studi Ilmu Kelautan FMIPA Universitas Sriwijaya, Indralaya. 